\title{
11 YEARS OF DECENTRALIZATION: HOW DO LOCAL PEOPLES THINK ABOUT DECENTRALIZATON?
}

\author{
George Towar Ikbal Tawakkal¹ - Thomas R Seitz² - Andrew D Garner ${ }^{3}$
}

\begin{abstract}
Law 32/2004, changing the face of local government, from centralization to decentralization. Decentralization is not only related to administrative stuff but also politics. The law gift rights to society to participate in local governance. It means, hopefully, that democracy values which become the spirit of decentralization, can be applied by local peoples. Through participating in governance, peoples can maximize local development. After one decade, decentralization presenting various achievements. Some cities or regencies, such as Surabaya City, can develop quickly, but others slowly. Different achievement and similar opportunity among them produced questions about how local peoples understand decentralization. Generally, this article will talk about two big questions: how do local peoples think about democracy? and, how do local peoples see political instruments in local level?. This article is based on a survey in Surabaya City during May 2016. Survey have conducted by questionnaire to 1023 respondents

The result showed that local people limit the meaning of decentralization. 50,7\% respondents were not interested in general political issues, and only $7.5 \%$ who were interested. The numbers explained that Surabaya peoples tend to be apathetic to politics. Even, the survey also found only $21.3 \%$ respondents who believe that democracy is a way to welfare. But, when respondents were asked question about the priority of meaning of democracy, 25.8\% respondents (high percentage) see democracy as an opportunity to change the government. They seen local election (Pilkada) is the opportunity, choose people who will be local government leader. We can conclude that Surabaya peoples did not apply democracy values (all kind of political participations) completely, in local governance, but they were interested in having a good leader. That why Surabaya peoples see political decentralization is a local election (Pilkada).
\end{abstract}

Keywords: decentralization, limit, local election

\section{Introduction}

Decentralization, in Indonesia, has been started since 2004, by implementing Law 32/2004 about Local Governance4. Even, Indonesia have Law 23/2014 about Local

\footnotetext{
${ }^{1}$ Lecturer at Department of Governmental Studies, Brawijaya University.

${ }^{2}$ Lecturer at Global Studies Area, University of Wyoming.

${ }^{3}$ Lecturer at Department of Political Scineces, University of Wyoming.
} 
Governance, which changes Law 32/2004. During 2004 until now, decentralization has worked for 11 years more. During the time, local governments show various achievements. Some cities or regencies still far from good governance. Such as Pradjasto (2012) statement, that democratization process in Indonesia is not yet able to overcome monopolization of political, social, and, especially, economic resources. Decentralization-whose agenda is not to centralize sources of power at the centerhas not been sufficiently successful in overcoming economic disparities among regions. Also, refer to President Regulation (2015), there are 121 regencies with poor categorize, which need priority program for 2015-2019.

Another side, Some local governments success to build a good government. For example, there are seven local governments that have had most innovative leaders, namely Semarang City, Sibolga City, Surabaya City, Bandung City, Mojokerto City, Kediri City, and Makassar City (Kemendagri, 2016). Kemendagri (Kepmendagri, 2016) also published rank of local governments performance. It showed gap of achievements among them. For regencies, the highest point is 3.4370 , and lowest point is 0,4353 . For cities, the highest point is 3,2920, and lowest point is 1,2995 . For provinces, the highest point is 3,0478 , and lowest point is 1,8534 .

The Asia Foundation (2011) made the rank of local economic governance. The result, there was gap of achievements among them. Local government with the highest point is 80.5 , and lowest point is 39.4 . The data also showed that there were 62 local governments with bad achievement in economic governance.

Ranking has been done in practicing democracy in local governments, also. Indonesia democracy index (IDI, 2016) shown, generally, democracy in Indonesia is fluctuated. By 0-100 scale, 2009 Indonesia democracy index is 67.30. In 2010, the index has decreased to 63,17 . But, in 2011 , the index has increased to 65,48 . Then, has increased to 62,63 in $2012,63,68$ in 2013 , and reached 73,04 in 2014 . The increasing was influenced by three factors: civil freedom, political rights, and democratic institutions. But, in 2015, the index has decreased to 72,82. Similar with increasing, the decreasing was influenced by decreasing of the three factors. Although Indonesia democracy index was fluctuated, that still place Indonesian on the middle level of

${ }^{4}$ Local Governance refer to Provincial, City, and Regency government 
democracy performance, not on the high or good level. They made three categories of democracy level: good $(>80)$, middle $(60-80)$, and bad $(<60)$.

Considering all achievements above, local governance performance and democracy performance, there is an interested phenomenon in East Java ${ }^{5}$. On democracy performance ranking, its index was fluctuated, and out of good local democracy performances. East Java got 62,49 point in 2009 , then decrease to 55,12 in 2010 . But, in 2011 , it increases to 55,98 , then decreases to 54,99 in 2012 . In 2013 , it increases to 59,32 , then increase highly to 70,36 , and reach to 76,36 in 2015 . Those scores still place East Java on the middle level of democracy performance.

With the scores (middle), in fact, East Java succeeded to get the highest score to become the best governance performance in provinces category (Kepmendagri, 2016). Also, cities and regencies in East Java dominated best of local governance performances. 2014 Evaluation of Local Governance Performance brought Surabaya City to the highest score and the best on city government category. Even, the mayor succeed to become the second runner-up of 2014 best mayors in the world (World Mayor, 2014). On local economic governance index (The Asia Foundation, 2011), there were 11 cities or regencies in East Java which in top twenty of best local economic governance performances. Blitar City was the best among local governments in Indonesia.

Achievement on democracy index, as middle level, and good achievements on governance performances produces a question about the relation between practicing democracy and local governance performance, in decentralization context. In another hand, Law 32/2004 and Law 23/2014 focused on people's participation when practicing decentralization. Considering difference achievements and laws, this article will answer how local peoples think about decentralization. This article will talk about five parts. First, we will discuss the relation between decentralization and democracy. Second, we will talk about what local peoples think about politics. Third, we will go to what they think about democracy. Fourth, understanding the meaning of decentralization in peoples. Fifth, we will make a conclusion. As a note, before implementing decentralization, Indonesia practiced centralization in Soeharto administration. Schiller (1993:3) said that Soeharto administration practiced "festival democracy", where there

\footnotetext{
${ }^{5}$ East Java is one of provincies in Indonesia
} 
was manipulated democracy, far from real democracy. He also mentioned Indonesia is one of most manipulated democratic countries. Referring to the situation, we will show survey data based on age categories of respondents, in order to understanding people's views who was adult in Soeharto era ( $>40$ years old ), who have grow up in transformation era (31-40 years old), and who still child or did not see Soeharto era (1730 years old)

This article is written based on a survey in Surabaya City, one of the cities in East Java Province, on 2016, May, with 1.023 respondents. We decided respondents by taking all districts (33 districts) in the city. In each district, we have 33 respondents, who were gotten from two kelurahan ${ }^{6}$, one is kelurahan, in the centre of the district, other is about the border with another district. In each kelurahan, respondents were decided randomly, then were asked to answer questionnaires. In the survey, $11.4 \%$ are respondents aged $17-22$ years, $15.8 \%$ are aged $23-30$ years, $25.7 \%$ are aged $31-40$ years, $22.7 \%$ are $41-50$ years, $16.3 \%$ are $51-60$ years, and $7.8 \%$ are respondents aged more than 60 years. There are respondents who did not mention their old, $0.3 \%$.

\section{Decentralization and Democracy}

Legality of decentralization in Indonesia is Law $32 / 2004$, which was changed to Law 23/2014. The laws mentioned clearly values of democracy, as the spirit of decentralization. Since Law 32/2004, in considering part of the law, letter a, explain that decentralization is directed to build welfare society through repairing public service, empowerment, participation, by values of democracy, equality, and justice. Section 22, letter c, explained about local governments have to build democracy life in decentralization. Section 27, verse 1, letter d, explained local government leaders have to do the democratic behavior. Not only them, legislators also have to do it, section 45 , letter b. Section 150, verse 3, letter d, explained how peoples have to participate in local development planning. In explanation part of the law, democracy was defined as following up aspiration, participation, and complaint from peoples.

Recent law, Law 23/2014, also placed values of democracy as the spirit of local governance. In considering part of the law, letter $b$, explain that decentralization is

\footnotetext{
${ }^{6}$ Kelurahan is village level in city, lowest government area.
} 
directed to build welfare society through repairing public service, empowerment, participation, by values of democracy, equality, and justice. Even, the law has a special chapter (Chapter IX) talk about participation in local governance. Section 25 verse 1 letter c, explained democracy is part of local conflict resolutions, then in letter $\mathrm{f}$ mentioned that democracy is part of local government affairs. In explanation part of the law, democracy also was defined as following up aspiration, participation, and complaint from peoples. Totally, the law mentioned democracy and participation word in 35 times

Theoretically, Mezey (2008) seen democracy, as popular sovereignty, that people have the final say about the policies that govern their lives. Majority decide the public policies that will govern their behavior. But, democracy guarantee that political right of the minority-rights such as freedom of speech and the press and the right to assemble-be protected. Mezey (2008) also argued that direct democracy can live in small, local or private groups. He also did not agree that value of democracy can be found in the modern nation state. In the modern state, Trias political doctrine makes peoples can not govern directly as they do in democracies. Modern states have a legislative institution as representative systems. Mezey seen representative systems are not democratic because of self-government, which is what democracy means, is not the same thing as government by someone else, even if you elect that someone to do the governing on your behalf. In spite of representation is believed as indirect democracy, some political theorists have argued that representation frustrates democracy by removing political decision-making from the hands of the people and giving it over to a select group of citizens who actually govern (see Junaenah, 2015). Emphasizing on the role of people in decision making, Mezey notes that citizens in a representative system have no direct role in the making of public policy.

What Mezey though looks good, but can not be operated in modern states, also he did not define "small, local" clearly as a hierarchy of government. Too difficult to involve all peoples to every decision making. That why scientist tried to take democracy near to more people. Political scientist argued (see Junaenah, 2015), that peoples have opportunities to participate in governance. But, will be more effective in local governance.Local government can be responsive to local goods and local values. Grindle (2007) seen important reasons for citizen participation in local elections and 
government decision making as a palliative to over centralized and authoritarian governments. Grindle (2007) mentioned, more effective democratic states needed strongly participatory local democracy. Grindle develops hypotheses to support decentralization in democratic local government. She focuses on political competition, state entrepreneurship, public sector modernization, and civil society activism. According to political competition perspective, Grindle (see Junaenah, 2015) believes that-as local elections are competitive, and opposition parties have real opportunities to win the position of authority, incumbents will be motivated to prove their competence in the management of public affairs and will seek to find new ways of addressing important problems. For this State entrepreneurship, the innovative measure is necessary. Related to the strategic behavior, the public sector modernization is supposed to be encouraged the performance on which it can be expected -to reflect inputs for capacity building, organizational reengineering, and restructuring how public services are delivered $\|$. The unattainable factor as the consequences of decentralization is the civil society activism. Grindle notes this factor as an extension to which local citizens are mobilized and demand accountability. It reflects the important of the social group in the local community to exert their opportunity to participate in decisionmaking and to urge the public sector to provide better services. The conclusion is, decentralization is a way to make people become more democracy.

Refers to laws and political scientist's arguments, those become a reason for us to think decentralization as practicing democracy. We see decentralization is democratization in local. It means, local peoples are main actors in decentralization. Local peoples play an important role to practice democracy, by participating in local governance. We will not talk about their behavior, but will talk about basic element of them, it is "how do local peoples think about decentralization?", with talking focus on how local peoples think about politics and democracy in this article.

\section{How Do Local Peoples Think About Politics?}

In the survey, we did not give a clear definition of politics to respondents. We let respondents see politics as what the think. Why we did not define it, is because we avoid influencing answering. If we defined those politics as good values, so will influence their 
answer. The survey showed that $50.7 \%$ respondents were not interested in politics, and only $7.5 \%$ respondents who really interested to politics. The percentages give understanding that majority is apathetic peoples. By relating to age categories, we found that respondents who were an adult in non-democratic government ( $>40$ years old) have a higher percentage in the age category, for an answer not interested in politics. Respondents who still a child or never seen non-democratic government (17-30), have a lower percentage. $50.4 \%$ respondents aged $41-50$ years stated they were not interested in politics. Even $65.0 \%$ respondents aged more than 60 years stated they were not interested in politics. 51.3\% respondents who grew up in the non-democratic era, also said that they were not interested in politics. For respondents who still a child or never seen non-democratic government, 46.9\% respondents aged 23-30 years were not interested, and only 29.9\% respondent aged 17-22 years were not interested in politics and have the highest percentage (11.1\%) among age categories who interested to politics. From all respondents who were interested, $52.5 \%$ are respondents aged more than 40 years, and $26.0 \%$ are respondents aged $31-40$ years. The percentages show respondents who adult and grew up to adult in non-democratic era tend to not interested, even after more than 15 years in the democratic era.

To confirm data above, we proposed other question about how much they follow political news. $49.9 \%$ respondents follow political news rarely, and $27.4 \%$ respondents never followed. The percentages show that majority did not follow political news. Just $12.9 \%$ respondents followed it every day. By relating to age categories, we found that respondents who were an adult in non-democratic government ( $>40$ years old) have a higher percentage in the age category, for answer never followed political news. $27.6 \%$ respondent aged 41-50 years did not follow political news. 37.7\% respondents aged 5160 years did not follow, then highest percentage, $37.7 \%$ respondents aged more than 60 years did not follow it. $23.2 \%$ respondents who grew up in the non-democratic era, also said that they did not follow it. For respondents who still a child or never seen nondemocratic government, 22.2\% respondents aged 23-30 years never followed political news, and only $17.9 \%$ respondent aged 17-22 years said that they never followed it. From all respondents who never followed political news, $57.9 \%$ are respondents aged 
more than 40 years. It means, respondents who were an adult in non-democratic era tend to not followed political news.

We also proposed other question to confirm data above. That is how much they talk about politics. $42.3 \%$ respondents never talked about politics, and $46.6 \%$ respondents talked politics rarely. never followed. Only 6.6\% respondents often talked politic. The percentages show that majority did not place politics as the theme of social discussion.

By relating to age categories, we found that respondents who were an adult in nondemocratic government ( $>40$ years old) have a higher percentage in the age category, for answer never talked about politics. 41.4\% respondent aged 41-50 years said never talked about it, and 53.9\% talked rarely. 52.7\% respondents aged 51-60 years never talked it, and 34.1\% talked rarely. 66.2\% respondents aged more than 60 years never talked it, and $26.2 \%$ talked rarely. $39.5 \%$ respondents who grew up in the nondemocratic era, also said that they never talked it, and 51.0\% respondents talked rarely. For respondents who still a child or never seen non-democratic government, $34.6 \%$ respondents aged 23-30 years never talked it, then only 30.8\% respondent aged 17-22 years said that they never talked it. From all respondents who never talked about politics, $54.7 \%$ are respondents who lived in the non-democratic era. While, from all respondents who talked it every day, $57.5 \%$ are respondents who still a child and never seen non-democratic era. It means, respondents who were an adult in non-democratic era tend to never talk about politics.

Percentages above, about following political news and talking about politics, confirm high percentage of respondents who were not interested in politics. Respondents who were an adult in the non-democratic era, also centralization era, have the highest percentage to be not interested in politics. The highest percentage, then, is confirmed by low percentage to follow political news and low percentage to talk about politics. Opposite, respondents who still a child or never seen non-democratic and centralization era, have the highest percentage to be interested in politics. The highest percentage, then, is confirmed by higher percentage to follow political news and a higher percentage to talk about politics. But, generally, the majority were not interested in politics. 


\section{How Do Local Peoples Think About Democracy In Local?}

Different with a question about politics above, in question about the meaning of democracy we gift four options to answer. The options are, the opportunity to change the government, freedom to speak, a little gap between rich and poor, and main goods available. $25.8 \%$ respondents assumed democracy is an opportunity to change the government. $21.4 \%$ respondents assumed democracy is freedom to speak. $7.4 \%$ respondents assumed democracy is little gap between rich and poor. $12.5 \%$ respondents assumed democracy is main goods available. The data show that highest percentage is respondents who defined democracy as opportunity to change government. In another word, democracy is local leader election (Pilkada)

Referring to a highest percentage, we see interested phenomena when to relate to age categories of respondents. Respondents in each age category, they have the highest percentage to think democracy is an opportunity to change the government. For respondents aged 17-22 years, highest percentage $(20.5 \%)$ is for the opportunity to change the government. For respondents aged 23-30 years, highest percentage (30.2\%) is for the opportunity to change the government. For respondents aged 31-40 years, highest percentage (28.5\%) is for the opportunity to change the government. For respondents aged 41-50 years, highest percentage $(25.4 \%)$ is for the opportunity to change the government. For respondents aged 51-60 years, highest percentage (24.6\%) is for the opportunity to change the government. Then, for respondents aged more than 60 years, the highest percentage $(20.0 \%)$ is for the opportunity to change the government. The percentages show that respondents who have seen non-democratic and centralization era, and respondents who never seen it, they defined local democracy in a same way, democracy is an opportunity to change the government.

We also propose other question about democracy. It is about believing that democracy can bring peoples to welfare. $60.3 \%$ respondents believed that democracy can do it, although the percentage consist two quality of believe. $21.3 \%$ respondents said they believe it, and 39.0\% respondents somewhat believe. The survey also showed that $35.3 \%$ respondents did not believe it. It means, the majority have trust value for democracy as a way to welfare. 
When we relate the data to age categories, we found an interested thing. Percentage about unbelieving will increase in old peoples. For respondents aged 17-22 years, $18.8 \%$ respondents did not believe democracy as a way to welfare, and increase to $38.8 \%$ for respondents aged 23-30 years. For respondents aged 41-50 years, 40.5\% did not believe it, increase to $41.9 \%$ for respondents aged 51-60 years. But decreasing to $36.2 \%$ for respondents aged more than 60 years. For all respondents who did not believe it, $53.4 \%$ respondents are respondents aged more than 40 years. It means, a respondent who were adult in non-democratic and centralization era tend to can not believe democracy as a way to welfare.

The percentages above show, although all age categories have highest percentage for seeing democracy as an opportunity to change the government, but they have difference percentage for believing democracy. A higher percentage of respondents aged more than 40 years, they assumed democracy as an opportunity to change the government, but, in another side, highest percentage mentioned they can not believe democracy as a way to welfare. Opposite, a higher percentage of respondents aged less than 40 years, they also assumed democracy as an opportunity to change the government, but, different with older, highest percentage mentioned they believe democracy can bring them to welfare. It means, respondents who were an adult in nondemocratic and centralization era assumed democracy as the local election (Pilkada), but can not believe democracy as a way to welfare.

\section{Meaning of Decentralization}

All percentages above show how Surabaya peoples think about politics and democracy. Generally, local peoples were not interested in politics, they have the low intensity to follow political news, and also a low intensity to talking about politics. But, when we proposed more detail questions, about democracy, they show views which look like they were interested in politics. From all respondents who were not interested in politics, $50.1 \%$ respondents believe democracy can bring peoples to welfare, and 21.4\% (highest percentage) assumed democracy as an opportunity to change the government. 
Local peoples tend have apathetic when faced with politics term. We also conducted in-depth interview about it. We found, the apathetic is influenced by how they see politics. They see political conflicts as the definition of politic. In another side, they presented another shape of interest. They believe democracy can bring peoples to welfare. So, we can understand it as, basically, their attitude toward politics can not be concluded as real apathetic attitude toward all things about politics.

More explanation will be found when we analyze age and interest to politics. More peoples who were not interested in politics are peoples who were an adult in nondemocratic and centralization era. We assumed, they have experience in non-democratic and centralization era, which influence how they think politics. Authoritarian, repressive policy, and manipulated elections in Soeharto era, influence them to think that politics is bad. So they were not interested in politics.

Referring to the Laws and political scientist arguments, we can discuss why the middle level of democracy index can produce good governance performance. We can explain it by understanding the meaning of decentralization, and we can get the understanding by knowing how local peoples think about democracy. Local people assumed democracy as the local election (Pilkada). It means, they assumed decentralization is a local election. Also, they have a young generation who believe democracy can bring them to welfare. Case in Surabaya City, local peoples see local election is the best way to welfare. They used the way well, voting for good people, then they have a good leader who can produce good governance. All is about local elections, then all is about the leader.

\section{Conclusion}

Surabaya peoples have limited when they think about decentralization. Ideally, they think decentralization is practicing values of democracy (see Law 23/2014). Automatically, they have to think about participating in all local governance aspects, from voting in a local election, participating in local development planning, until participating in implementing local policy. But, actually, Surabaya peoples think democracy as an opportunity to change the government (local election). In a simple 
conclusion, decentralization is a local election. It looks they bet five years of government period on a local election.

\section{Bibliography}

Anton Pradjasto, Anton, and Irwansyah, Dirga Ardiansa, Roichatul Aswidah, Sri Budi Eko Wardani,Wawan Ichwanuddin, Yolanda Panjaitan. (2012). “(De)Monopolization Of Democracy In Indonesia? The Indonesian Report On The Asian Democracy Index 2011". Asian Democracy Review Vol. 1 (2012): p.108-132

Grindle, M.S. (2007). Going Local, Decentralization, and the Promise of Good Governance. New Jersey: Princeton University Press

IDI Project. (2016). "Indeks Demokrasi Indonesia 2015". Accessed from www.idiproject.org on 15 Agustus 2016.

Junaenah, Inna. (2015, May). "Indonesian Democratic Index: The Effort to Encourage Democratic Provincial Government". International Journal of Social Science and Humanity, Vol. 5, No. 5: p. 466-471

Kepmendagri Nomor 800-35 Tahun 2016 Tentang Penetapan Peringkat Dan Status Kinerja Penyelenggaraan Pemerintahan Daerah Secara Nasional Tahun 2014

Kemendagri. (12 Agustus 2016). "Walikota Makassar Kembali Dinobatkan Sebagai Walikota Terinovatif 2016". Accessed from www.kemendagri.go.id on 15 Agustus 2016

Mezey, M.L (2008). Representatives Democracy, Legislators, and Their Constituents. Maryland: Rowman and Littlefield Publishers Inc.

Peraturan Presiden Nomor 131 Tahun 2015 tentang Penetapan Daerah Tertinggal Tahun 2015-2019

Schiller, Jim. (1999, May) “The 1997 Indonesian Elections: 'Festival of Democracy' or Costly 'Fiction'?". Occasional Paper.

The Asia Foundation. (2011). "Tata Kelola Ekonomi Daerah 2011". downloaded by www.asiafoundation.org .

Undang-Undang Nomor 23 Tahun 2014 tentang Pemerintahan Daerah

Undang-Undang Nomor 32 Tahun 2004 tentang Pemerintahan Daerah

World mayor. (2014). "The 2014 Winners". Accessed from www.worldmayor.com on 16 Agustus 2016 